\title{
Études/Inuit/Studies
}

\section{Inuit identities in Montreal, Canada}

\section{Nobuhiro Kishigami}

Volume 26, numéro 1, 2002

Perspectives inuit et qallunaat : points de vue en interaction Inuit and Qallunaaq perspectives: Interacting points of view

URI : https://id.erudit.org/iderudit/009279ar

DOI : https://doi.org/10.7202/009279ar

Aller au sommaire du numéro

\section{Éditeur(s)}

Association Inuksiutiit Katimajiit Inc.

ISSN

0701-1008 (imprimé)

1708-5268 (numérique)

Découvrir la revue

Citer cette note

Kishigami, N. (2002). Inuit identities in Montreal, Canada. Études/Inuit/Studies, 26(1), 183-191. https://doi.org/10.7202/009279ar

\section{Résumé de l'article}

Comme Dorais (1994) l'a indiqué, il est important de faire une distinction entre les concepts d'identités culturelles et ethniques afin de comprendre les identités des Inuit contemporains du Canada. Bien que les Inuit ne distinguent pas eux-mêmes ces identités, je les considère comme étant des concepts analytiques pratiques. Je suggère donc que l'identité culturelle est un outil utilisé par l'Inuk dans sa vie quotidienne avec d'autres Inuit alors que l'identité ethnique est un outil politique que les Inuit urbanisés et ceux de l'Arctique utilisent pour faire face à des situations multi-ethniques. 


\section{Notes de recherche / Short Papers}

\section{Inuit identities in Montreal, Canada}

\section{Nobuhiro Kishigami*}

\section{Résumé: $\quad$ Les identités inuit à Montréal, Canada}

Comme Dorais (1994) l'a indiqué, il est important de faire une distinction entre les concepts d'identités culturelles et ethniques afin de comprendre les identités des Inuit contemporains du Canada. Bien que les Inuit ne distinguent pas eux-mêmes ces identités, je les considère comme étant des concepts analytiques pratiques. Je suggère donc que l'identité culturelle est un outil utilisé par l'Inuk dans sa vie quotidienne avec d'autres Inuit alors que l'identité ethnique est un outil politique que les Inuit urbanisés et ceux de l'Arctique utilisent pour faire face à des situations multi-ethniques.

\section{Abstract: Inuit identities in Montreal, Canada}

As Dorais (1994) has indicated, the distinction between the concepts of cultural and ethnic identities are important for us to understand the identities of contemporary Canadian Inuit Although the Inuit themselves do not distinguish between these identities, I consider them to be useful analytical concepts. I argue that cultural identity is a tool for an Inuk to live with his fellow Inuit in daily life and that ethnic identity is a political tool especially for both urban and arctic Inuit to deal with others in multi-ethnic situations.

\section{Introduction}

By the late 1990s, approximately $17 \%$ of all Canadian Inuit lived in urban centres in southern Canada (Kishigami 1999a, b, c). Thus, in order to understand the identities

National Museum of Ethnology, Osaka, Japan. 
of Canadian Inuit, we need to include the study of identities of Inuit living both in arctic villages and in the southern cities of Canada.

In this paper, I suggest that although many urban Inuit, except those who come down south as adults ${ }^{1}$, have difficulty sustaining their cultural identity in multi-ethnic situations, they maintain their ethnic identity as an invisible boundary against other ethnicities. The difference between being a "real Inuk" and being a member of the Inuit people is acquired in this context, according to data recorded during research among urban Inuit in Montreal (Kishigami 1999a, b, 2000).

\section{Concept of identity and theoretical perspective}

People need to know their position in society in order to have a frame of reference for social interaction with other members of that society. Each person forms social relations and interacts with others according to one or more identities and, as they grow, they gain multiple social roles and identities. At any given time, a person interacts with others by employing one identity or a combination of several ones. As a society becomes more complex and diverse, the problem of a person's identity becomes critical and increasingly significant in her or his life (Barth 1969).

Identity is the representation of a person's or a group's particular place in the world. It may be self-ascribed, defined by others, or both. Generally, a person has several identities at a given time, and those identities may change over her or his lifetime.

Dorais distinguishes cultural identity from ethnic identity. He defines the former as "a fundamental consciousness of the specificity of the group to which one belongs in terms of ways of living, customs, languages, values, etc." (Dorais 1994, translated in Gombay 2000: 254). According to Dorais (1994), before participation in non-Inuit economic, social, and political systems, Inuit had a sense of cultural identity that distinguished them from other people and other living things. Cultural identity is related to all domains of daily life, but ethnic identity is a politicized cultural identity (Lanting 1999: 135). The latter is "connected with the political domain and becomes manifest in relation to and confrontation with others within the context of larger political arena, state" (Lanting 1999: 135) ${ }^{2}$. Ethnic identity, one of a person's identities, develops and serves as a frame of reference for social practice only in multi-ethnic societies (Lambert 1986; Dorais 1994).

In a sense, ethnic identity and aboriginal ethnicity apparently emerged among the Inuit of Canada in the 1970s. Aboriginal people in the Canadian Arctic have become

1 It is true that urban Inuit who came south as adults have an Inuit world view. Although some aspects of cultural identity, such as those based on hunting, daily food sharing, languages, and social relations, are impossible or difficult to maintain in Montreal, the spiritual and psychological aspects of Inuit culture are still important to most adult urban Inuit (Dorais 2000, personal communication). All Inuit, in the North and the South, have both cultural and ethnic identities. But most urban Inuit encounter serious difficulties in realizing their cultural identity. "ethnicity as the politics of culture" (Paine 1983: 212). 
the Inuit, a specific nationality within a larger Canadian state composed of many peoples. As the Inuit developed this awareness, they followed the example set by other aboriginal peoples in Canada and in the 1970s started negotiating land claims (Stewart 1998; Gombay 2000: 134).

The Inuit themselves do not recognize the subtle distinction between cultural and ethnic identities. However, on the basis of my research experience with Inuit people in Montreal and Nunavik in the 1980s and 1990s, I think the difference between the two is significant in understanding the historical change and continuity of Inuit identities in Canada

\section{Inuit identities in Montreal}

\section{Urban Inuit in Canada}

During the 1980s many Inuit born in the Canadian Arctic began to move to southern cities (Kishigami 1999 a, b, c; Royal Commission on Aboriginal Peoples 1993; Frideres 1999: 235-247). By 1991, there were 8,305 Inuit living in Canadian cities with a population of 100,000 or more (Canadian Council on Social Development 1996: Table 1). The word "Inuit" here refers to persons who claimed a full or partial Inuit identity at census time. Since the overall Canadian Inuit population was 49,000 individuals in 1991, this means that about $17 \%$ of these people lived in southern metropolises.

The Inuit population in Canadian cities in 1991 was 1,895 in Toronto, 840 in Edmonton, 775 in Montreal, 725 in Ottawa-Hull, 630 in Calgary, 570 in Vancouver, 515 in Winnipeg, 360 in Halifax, 345 in Saint John's, and 260 in Victoria. Thus, Montreal had the third largest population of urban Inuit in Canada.

\section{Urban Inuit in Montreal}

Montreal is the second largest city in Canada, after Toronto. The total population of the Greater Montreal District is about 3.1 million. According to the 1991 census, the ethnic composition of the population is approximately 1.8 million (59\%) French, 206,000 (6.7\%) English, 166,000 (5.4\%) Italian, 77,000 (2.5\%) Jewish, and 550,000 (26.4\%) from various other ethnic groups. Montreal thus constitutes a multi-ethnic society, although because French Canadians numerically, politically and culturally dominate the city, French is the first language.

The Montreal Inuit may be divided into three occupational categories: students, workers $^{3}$, and jobless persons. While Inuit workers or students can live well in Montreal, those without jobs only manage to survive by having recourse to charitable

3 The workers include wage earners working at political, cultural, educational, and medical organizations, and those who are self-employed. 
organizations and government welfare. Many of the jobless Inuit encounter severe socio-economic problems in the city (Kishigami $1999 \mathrm{a}, \mathrm{b}$ ).

Given the urban setting, Montreal Inuit are unable to undertake traditional pursuits such as hunting and fishing. However, they do speak with their northern friends in Inuktitut, and sometimes share some country foods that have been sent or brought from the North. This meat and fish is either portioned out to other Inuit, or the Inuk who possesses it invites other Inuit to share meals. As there are very limited quantities of Inuit country food in the city, food sharing and invitations to meals occur only occasionally. Although some Inuit produce soapstone carvings or handicrafts in Montreal, there are hardly any other ethnic and cultural distinctions between urban Inuit life-ways and those of other city-dwellers. Most of the Inuit accommodate to existing urban institutions rather than maintaining their northern way of life in the city.

Inuit women in Montreal tend to live with or marry non-Inuit partners, and their children tend not to speak Inuktitut or retain an Inuit cultural identity. The urban settings of multi-ethnic cities lack the social conditions for maintaining Inuit culture and language.

My research of 1996 and 1997 indicates that young Inuit raised in Montreal and Inuit whose spouse or a parent is non-Inuit begin to regard themselves as Aboriginals of Canada, Canadian of Inuit descent, or indigenous people of Quebec, rather than as Inuit (cf. Lambert 1986; Fienup-Riordan 2000: 151-168). According to the 1991 Aboriginal census, 455 of the 775 Montreal Inuit listed multiple ethnic identities. Interethnic marriages over one generation and city dwelling in multi-ethnic situations make Inuit's intergenerational succession of their language and culture difficult, and they lose their taste for country food ( $c f$. Fogel-Chance 1993; Sprott 1994; Fienup-Riordan 2000: 151-168; Lee 2000).

\section{Creation of the Association of Montreal Inuit}

Until the late 1990s, there were few places for Inuit to meet and exchange information in Montreal. As Inuit of Montreal did not have any voluntary association and did not form a spatially separate community, they had to create individual social networks amongst themselves. This resulted in the lack of extensive food sharing and only occasional use of Inuktitut. Generally speaking, most Montreal Inuit could not create and maintain Inuit culture and cultural identity primarily because they lacked strong social solidarity and because their social networks were too weak.

In 1998, a number of Montreal Inuit became concerned about the situation and held several meetings to discuss the establishment of an urban Inuit organization. When they held a country food feast at the hall of St. Paul's Anglican Church in Lachine one Saturday in November, 1999, about 120 Inuit attended. The group decided to voluntarily hold monthly community-style Inuit country food feasts. Such feasts are prevalent in northern villages during special times of the year, such as Christmas and Easter (Mesher 2000). 
On March 29, 2000, a volunteer organization, the "Association of Montreal Inuit," was officially established (Mesher 2000). This organization aims to function as a center for information exchange, socializing, and to providing a monthly supper for urban Inuit. This new organization provides urban Inuit with a social base for maintaining cultural as well as ethnic identities. If this organization is successful, the Inuit of Montreal may be able to maintain their cultural identity and create a new sense of a Montreal Inuit community.

\section{Inuit identities in Montreal}

Cultural identities of most Inuit living in Montreal have always been threatened by multi-ethnic situations under the domination of Québécois (French Canadian Quebec residents). As previously discussed, Montreal Inuit live and interact frequently with non-Inuit populations in this multi-ethnic city and lack conditions for fostering sociocultural Inuit life-ways. Under these conditions, ethnic identity and ethnic symbols associated with them take precedence over cultural identity and cultural traits. In Montreal, cultural identity and cultural traits are meaningful only when Inuit interact with each other.

If Inuit living in Montreal are recognized as beneficiaries of the James Bay and Northern Quebec Agreement or the Nunavut Agreement, they and their children may receive certain educational and medical benefits while residing in the city. As long as such benefits exist, some urban Inuit will intentionally retain their Inuit status even though they do not speak Inuktitut or maintain an Inuit way of life. In the future, a person officially classified as an Inuk, but without the cultural identity and lifestyle of arctic Inuit, will thus become common sight. These people will need ethnic symbols to indicate their difference from other ethnic groups and to keep their ethnic identity in the urban environment ( $c f$. Gans 1996).

As the frequency of interaction among Inuit from different regions has increased in the city, group amalgamation such as forming a Montreal group of Inuit from various arctic regions is occurring. Also, some persons who have a non-Inuit parent or ancestor express multiple ethnic identities. Furthermore, some second and third generation urban Inuit have been assimilated into the multi-ethnic society of Canada, politically and economically dominated by French and English Canadians. Thus, it appears that urban Inuit are using ethnic identity as an adaptive tool in a multi-ethnic city. This phenomenon is rarely in evidence in contemporary arctic villages except those large enough to have heterogeneous populations, such as Iqaluit and Kuujjuaq.

\section{Discussion}

In an arctic village, cultural identity is much more important than ethnic identity for Inuit in daily life. While Inuit living in arctic villages are reproducing their cultural identity through daily socio-cultural practices in appropriate Inuit ways, they usually do not need to express their ethnic identity in their daily life. 
Although cultural tradition has changed over time, it has furnished the Inuit with cultural values and behavioural orientations at any given time. In the late 1990s, the Nunavik Inuit had a distinctive culture but it differed from the past. Cultural identity is associated with being a real Inuk who interacts with others in contemporary appropriate Inuit ways. This identity is reproduced through socio-cultural practices, such as hunting, food sharing, and many other activities in the daily life of arctic villages, including Christian practices, playing a hockey game, etc. (Dorais 1997; Omura 1998; Lanting 1999; cf. also Brody 1975; Briggs 1997). As this identity is a basis for an Inuk to follow Inuit ways, it is not always related to being a member of the Inuit ethnic group.

In Montreal, the Inuit have difficulty sustaining their cultural identity primarily because they do not have the necessary opportunities to engage in activities in Inuit ways. Also, they interact with non-Inuit people in a multi-ethnic environment. Under these circumstances, cultural identity cannot always be the basis for a frame of reference for socio-cultural practices. Rather, ethnic identity will be much more important for urban Inuit living in multi-ethnic environments.

Inuit do not always need to follow socio-cultural practices in daily life in order to maintain their ethnic identity. They only have to demonstrate that they are different in some ways from non-Inuit peoples in Canada. In order to achieve political integration and show their distinctiveness as a group, they need ethnic symbols such as Inuit dances, plays, hunting traditions, Inuktitut, etc. To urban Inuit as well as Inuit politicians in the political arena, ethnic identity and ethnic symbols are an important and adaptive tool in their life and activities (Kishigami 1992; Briggs 1997).

\section{Conclusion}

Identity is becoming increasingly complicated and diversified for the contemporary Inuit of Canada. To be a real Inuk is not a necessary condition for being an ethnic Inuk (Brody 1975). In the late 1990s, as I have discussed, cultural identity was an important frame of reference for social interaction among Inuit, while ethnic identity was the primary frame of reference in urban settings and political arenas. The former is reproduced through socio-cultural practices in Inuit ways and the latter is reproduced primarily through interaction with other Inuit and non- Inuit, and the use of ethnic symbols in multi-ethnic environments.

As assimilation proceeds in multi-ethnic urban settings, persons with multi-ethnic identities are emerging. Most urban Inuit find it difficult to maintain or reproduce cultural identity in urban settings without a special community centre for them or close ties to home communities. Thus, the number of Inuit who do not maintain Inuit ways of life or language but maintain an Inuit ethnic identity will increase in the cities. A similar trend can be expected in arctic villages with large heterogeneous populations such as Iqaluit and Kuujjuaq, where ways of life are becoming more diversified. 
However, I should emphasize the role of a new voluntary organization (Association of Montreal Inuit) which was, as noted above, established in 2000. As this association provides urban Inuit with a monthly country food supper and other programs, it may contribute to an individual's sense of being a real Inuk and having a cultural identity. I think that success depends on the association maintaining some Inuit socio-cultural practices in Montreal ${ }^{4}$.

I argue that cultural identity is a tool for an Inuk to live with his fellow Inuit in daily life, and that ethnic identity is a political tool developed specially for both urban and arctic Inuit to deal with others in a multi-ethnic society. These two concepts will be useful in examining differences in Inuit life within arctic villages, symbolic discourse within political arenas, and in understanding differences between the arctic and urban lives of Inuit in Canada.

\section{Acknowledgments}

The original paper was read at the Fourth International Congress of Arctic Social Sciences (ICASS IV), on the $17^{\text {th }}$ of May 2001 in Quebec City, Canada. I thank Professors L.J. Dorais and G. Wenzel for their thoughtful discussion of Inuit identities. Also, I am grateful to Professors L.J. Dorais, Molly Lee, James Savelle and two anonymous reviewers for their comments and criticisms on my draft. Shortcomings are of course my own.

\section{References}

BARTH, Fredrik

1969 Introduction, in F. Barth (ed.), Ethnic Groups and Boundaries, Boston, Little, Brown: 9-38.

BRIGGS, Jean

1997 From Trait to Emblem and Back: Living and Representing Culture in Everyday Inuit Life, Arctic Anthropology, 34(1): 227-235.

BRODY, Hugh

1975 The People's Land, Harmondsworth, Penguin Books.

CANADIAN COUNCIL ON SOCIAL DEVELOPMENT

1996 Demographic Profile of Aboriginal Peoples in Major Canadian Metropolitan Centres, Prepared for the National Association of Friendship Centres, Ottawa.

DORAIS, Louis-Jacques

1994 À propos d'identité inuit, Études/Inuit/Studies, 18(1-2): 253-260.

4 Anthropological studies on urban Yup'ik and Inupiaq emphasize the importance of country food "sharing" practices in maintaining their solidarity and identity (Fogel-Chance 1993: 99, 101; FienupRiordan 2000: 116; Lee 2000). 
Quaqtaq: Modernity and Identity in an Inuit Community, Toronto, University of Toronto Press.

FIENUP-RIORDAN, Ann (ed.)

2000 Hunting Tradition in a Changing World: Yup'ik Lives in Alaska Today, New Brunswick and London, Rutgers University Press.

FOGEL-CHANCE, N.

1993 Living in Both Worlds: Modernity and Tradition in North Slope Inupiaq Women in Anchorage, Arctic Anthropology, 30(1): 94-108.

FRIDERES, J.S.

1999 Aboriginal Peoples in Canada: Contemporary Conflicts (fifth edition), Scarborough, Prentice Hall Allyn and Bacon Canada.

GANS, Herbert J.

1996 Symbolic Ethnicity: The Future of Ethnic Groups and Cultures in America, in W. Sollors (ed.), Theories of Ethnicity: A Classical Reader, London, Macmillan Press Ltd.: 425-459.

GOMBAY, Nicole

2000 The Politics of culture: Gender parity in the legislative assembly of Nunavut, Études/Inuit/Studies, 24(1): 125-148.

KISHIGAMI, Nobuhiro

1992 New Ethnicity in the Canadian Arctic, in K. Tanimoto (ed.), Hoppou Shominzoku Geinousai Houkoku, Sapporo, Hokkaido University of Education: 91-107.

1999a Life and Problems of Urban Inuit in Montreal: Report of 1997 Research, Jinbun-Ronkyu (Journal of the Society of Liberal Arts), 68: 81-109.

1999b Kanada niokeru toshizaijuu inuitto no shakai/keizai joukyou (Current Socio-Economic Situations of Urban Inuit in Canada: A Case study from Montreal), Bulletin of the National Museum of Ethnology, 24(2): 205-245.

1999c Why do Inuit move to Montreal? A research note on urban Inuit, Études/Inuit/Studies, 23(1-2): 221-227.

2000 Identities of Inuit in Canada: Being an Inuk and Being one of the Inuit, International Conference on Ethnicity and Identity in the North, ICNSA 3, October 12-14, Sapporo, Japan.

LAMBERT, Carmen

1986 Aboriginal Ethnicity in a Canadian Urban Context, in T. Ayabe (ed.), Ethnicity and Multiculturalism in Canada, Ibaraki, Institute of History and Anthropology, University of Tsukuba: 3-32. 
LANTING, Erik

1999 Identity in Tasiusaq, in J. Oosten and C. Remie (eds.), Arctic Identities: Continuity and Change in Inuit and Saami Societies, Leiden, Research School CNWS, School of Asian, African, and Amerindian Studies, Universiteit Leiden: 135-144.

LEE, Molly

2000 The Cooler Ring: Urban Alaska Natives and the Struggle for Subsistence Rights, Paper read at the Annual Meeting of the American Anthropological Association, November, San Francisco.

MESHER, Victor Jr.

2000 No Longer Alone: A Haven of Happiness with the Association of Montreal Inuit, Makivik Magazine, 54: 57-67.

OMURA, Keiichi

1998 Kanada Inuito no nijouseikatu niokeru imeiji (Self-image and Everyday Practices in Canadian Inuit Society), Minzokugaku-Kenkyu (The Japanese Journal of Ethnology), 63(2): 160-170.

PAINE, Robert

1983 Norwegians and Saami: Nation-State and Fourth World, in G.L. Gold (ed.), Minorities and Mother Country Imagery, St. John's, Memorial University of Newfoundland, Institute of Social and Economic Research: 211-248.

ROYAL COMMISSION ON ABORIGINAL PEOPLES

1993 Aboriginal Peoples in Urban Centres, Ottawa, Canada Communication Group.

SPROTT, Julie E.

1994 Symbolic Ethnicity and Alaska Natives of Mixed Ancestry Living in Anchorage, Human Organization, 53(4): 311-322.

STEWART, Henry

1998 Minzokukosho to imeiji (Ethnonyms and Images), Minzokugaku-Kenkyu (The Japanese Journal of Ethnology), 63(2): 151-159. 